Original Paper

\title{
Pengayaan Materi Olimpiade Fisika dan Pelatihan Penyelesaian Soal-Soal Olimpiade Fisika Bagi Guru dan Siswa di Sekolah Mitra
}

\author{
Susilawati $^{*}$, Aris Doyan ${ }^{1}$, Muhamad Taufik ${ }^{1}$ \\ ${ }^{1}$ Program studi pendidikan fisika, Fakultas Keguruan dan Ilmu Pendidikan, Universitas Mataram, Indonesia
}

DOI: $10.29303 /$ jpmpi.v2i1.315

Sitasi: Susilawati, et, al. (2019). Pengayaan Materi Olimpiade Fisika dan Pelatihan Penyelesaian Soal-Soal Olimpiade Fisika Bagi Guru dan Siswa di Sekolah Mitra. Jurnal Pengabdian Magister Pendidikan IPA (JPMPI). (2) 1.pp. 1-5

*Corresponding Author:

Susilawati, Program studi pendidikan fisika, Fakultas Keguruan dan Ilmu Pendidikan, Universitas Mataram, Indonesia;

Email:

susilawatihambali@unram.ac.id

\begin{abstract}
Abstrak: Tujuan kegiatan pengabdian pada masyarakat ini adalah untuk mempersiapkan siswa dalam menghadapi olimpiade fisika di tingkat lokal (kabupaten dan provinsi) dan untuk meningkatkan kemampuan peserta didik SMPN 9 Mataram dalam mengerjakan soal-soal olimpiade fisika. Manfaat dari pembinaan dan pelatihan olimpiade ini memberi efek langung pada kemampuan siswa SMPN 9 Mataram dalam penguasaan materi dan kemampuan mengerjakan soal-soal olimpiade fisika. Sebagai upaya menyelesaikan permasalahan tersebut di atas diadakan kegiatan pengabdian pada masyarakat sebagai sasarannya adalah guru dan siswa di SMPN 9 Mataram. Langkah-langkah kegiatan melalui tahap persiapan, tahap sosialisasi, tahap pelaksanaan, dan tahap evaluasi. Tahap persiapan diadakan diskusi tim pengabdian dengan kepala sekolah dan guru-guru IPA tentang silabus dan materi olimpiade yang akan disampaikan serta teknis pelaksanaan. Tahap selanjutnya diadakan kegiatan sosialisasi yang dihadiri pihak Dinas Pendidikan Kota Mataram, Kepala Sekolah dan Wakil kepala sekolah, guru-guru IPA dan para siswa yang mengikuti pengayaan. Kegiatan sosialisasi berisi pemberian informasi tentang kegiatan yang diberikan oleh dosen selaku Tim pengabdian. Tahap selanjutnya adalah tahap pelaksanaan, kegiatan ini diikuti oleh guru- guru IPA dan siswa yang berasal dari kelas VII sampai kelas VIII. Guru dan siswa diberi materi pembinaan berupa pemberian soal-soal olimpiade dan dilatih untuk menyelesaikan sendiri dengan tingkat kesulitan yang berjenjang. Ada dua aspek yang dievaluasi pada kegiatan ini, yakni kehadiran dan aktivitas peserta selama pelatihan berlangsung baik bertanya, menjawab pertanyaan dan berdiskusi. Hasil wawancara dengan peserta kegiatan diperoleh data bahwa kegiatan ini sangat bermanfaat karena telah memberikan pengetahuan dan pengalaman bagi peserta didik dalam menjawab soalsoal olimpiade fisika.
\end{abstract}

Keywords: Olimpiade fisika; Pelatihan; Pengayaan Materi.

\section{Pendahuluan}

Olimpiade Sains Nasional SMP Indonesia, dalam menghadapi Olimpiade fisika, kesiapan para siswa belum optimal dan masih mengalami banyak kendala, demikian halnya wawasan para guru pembimbingnya. Belum semua guru pembimbing olimpiade familiar dengan karakteristik dan perkembangan soal-soal olimpiade fisika. Olimpiade fisika
Kabupaten/Kota, khususnya bidang fisika merupakan bentuk kegiatan rutin yang di selenggarakan oleh tiap Kabupaten/Kota hingga provinsi secara nasional, untuk dapat diikutkan dalam kompetisi olimpiade internasional (Wikipedia, 2018). SMPN 9 Mataram dalam rangka menangkap peluang tersebut, maka perlu mempersiapkan siswa-siswinya dalam mengikuti kegiatan tersebut. 
Dalam upaya mempersiapkan siswa, SMPN 9 Mataram hendaknya guru pembimbing olimpiade terlebih dahulu diberikan pelatihan dan pembinaan khususnya guru pembimbing olimpiade fisika, sebab hingga saat ini guru pembimbing olimpiade belum pernah diberikan pelatihan dan pembinaan. Guru pembimbing olimpiade fisika hingga saat ini belum mendalami materi dan mengenal ragam soal beserta cara pemecahannya. Oleh sebab itu, sangat diperlukan pelatihan dan pembinaan guru pembimbing olimpiade fisika agar lebih memahami trend soal-soal beserta penyelesaiannya dan pengayaan materi fisika tingkat SMP.

Pelatihan dan pembinaan ini diharapkan dapat meningkatkan kualitas pembimbingan oleh guru untuk para siswa-siswi SMPN 9 sehingga menjadi lebih baik dan dapat meningkatkan kesiapan para siswa mengikuti Olimpiade fisika. Kondisi ini yang menyebabkan kegiatan ini terlaksana, karena pihak sekolah menginginkan pembinaan dan pelatihan yang di sajikan oleh pengajar yang lebih fokus dan lebih memahami persoalan fisika (Anonim,. 1991) (Depdiknas, 2018).

Berdasarkan analisa situasi di atas maka, dapat di rumuskan permasalahan sebagai berikut: Bagaimana meningkatkan kemampuan keterampilan dan analitik siswa dalam mengerjakan soal-soal olimpiade fisika Kabupaten/Kota (OSN) untuk mengikuti kompetisi OSN di tingkat kota/kabupaten, provinsi dan Nasional?

Kegiatan pengabdian ini bertujuan untuk meningkatkan kemampuan guru sebagai pembimbing olimpiade sains (fisika) dalam menganalisis penyelesaian soal-soal olimpiade dan metode membelajarkan siswa. Manfaat kegiatan Pengabdian Pada Masyarakat ini, untuk meningkatkan pemahaman guru sains dalam menganalisa penyelesaian soal-soal olimpiade dan bagaimana metode untuk melatih para siswa dalam menyelesaikan soal-soal tentang dinamika, termodinamika, gelombang, optik, listrik, dan magnet (Supriyadi, 2007), (Hidayat, 2018).

\section{Metode Pelaksanaan}

Menindak lanjuti keterbatasan dan kesulitan yang dialami guru dalam melakukan pembinaan olimpiade fisika terhadap siswa fisika maka disusunlah kerangka pemecahan masalah yang terbagi menjadi beberapa tahapan, yaitu: tahap persiapan, tahap pelaksanaan, tahap evaluasi dan pelaporan (gambar 1).

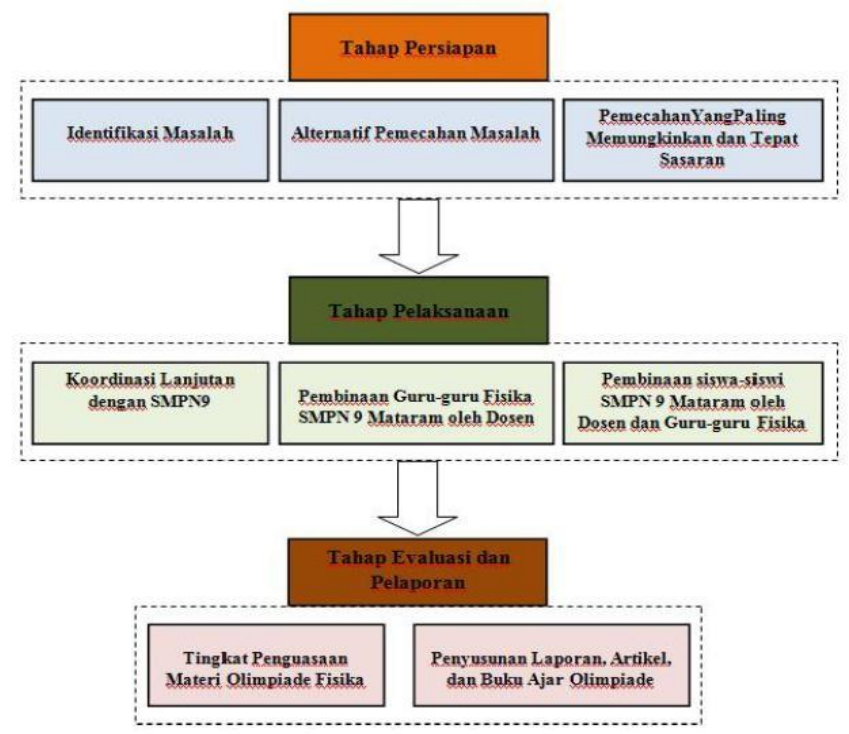

Gambar 1. Kerangka Pemecahan Masalah

Pada tahap persiapan; Tahap persiapan telah dilakukan dalam bentuk identifikasi permasalahanpermasalahan atau kesulitan-kesulitan yang dialami oleh guru pembimbing olimpiade IPA fisika SMPN 9 Mataram. Permasalahanpermasalahan yang telah diidentifikasi selanjutnya dicarikan alternatif-alternatif pemecahan yang paling memungkinkan dan paling tepat sesuai dengan karakter guru dan siswa yang ada di SMPN 9 Mataram. Pada tahap pelaksanaan; pelatihan dan bimbingan guru pembimbing olimpiade di SMPN 9 Mataram telah dilaksanakan dalam waktu dua bulan. Selanjutnya bimbingan kepada siswa telah dilakukan oleh guru pembimbing dan dipantau oleh dosen.

Proses pemantauan dilakukan sebagai upaya untuk memantapkan kemampuan guru dalam membimbing siswa-siswinya dalam menyelesaiakan soal-soal olimpiade fisika. Selanjutnya pada tahap evaluasi dilaksanakan untuk mengidentifikasi kekurangan-kekurangan dari pelaksanaan pembimbingan dan pelatihan. Evaluasi juga dilaksanakan pada kemampuan siswa dalam menyelesaikan berbagai bentuk soalsoal olimpiade.

Muara dari kegiatan ini adalah untuk meningkatkan penguasaan materi pembinaan olimpiade fisika SMPN 9 Mataram. Terkait 
dengan hal ini, khalayak sasaran yang strategis dan tepat untuk dilibatkan adalah guru IPA SMPN 9 Mataram sebanyak lima orang. Metode yang digunakan dalam kegiatan pengabdian pada masyarakat ini berupa diskusi, tanya jawab, dan problem solving soal-soal olimpiade.

\section{Hasil dan Pembahasan}

Keterkaitan Kegiatan, kegiatan Pengabdian Pada Masyarakat ini terkait khusus dengan guruguru IPA SMP N 9 Mataram. Hasil kegiatan ini tentu dapat meningkatkan kemampuan analisis penyelesaian soal-soal olimpiade dan membelajarkan dengan cara yang efektif kepada siswa peserta bimbingan olimpiade. Adapun evaluasi dilaksanakan di akhir kegiatan dengan cara meminta kepada para peserta kegiatan sosialisasi untuk mengungkapkan aspek positif dan aspek negatif yang dirasakan setelah mengikuti kegiatan dan meminta peserta untuk memberi saran-saran untuk perbaikan kegiatan yang akan datang. Keberhasilan kegiatan ini dapat dilihat dari banyak sedikitnya aspek positif dan aspek negatif yang dikemukakan oleh guru IPA pembimbing olimpiade dan siswa peserta bimbingan olimpiade.

Kegiatan pengabdian kepada masyarakat ini dilaksanakan dalam bentuk pembinaan melalui tahap persiapan, sosialisasi, pembinaan guru pembimbing olimpiade dan pembinaan siswa peserta olimpiade. Persiapan pelaksanaan kegiatan pelatihan guru pembimbing olimpiade dan siswa peserta olimpiade. Persiapan-persiapan yang dilakukan adalah koordinasi dengan kepala sekolah SMPN 9 Mataram dan menyiapkan bahan-bahan kebutuhan dalam pelaksanaan pengabdian seperti ATK, spanduk, konsumsi, dan transport kepada para peserta pembinaan. Pada tahap persiapan juga dilakukan identifikasi masalah, alternatif pemecahan masalah serta solusi pemecahan masalah.
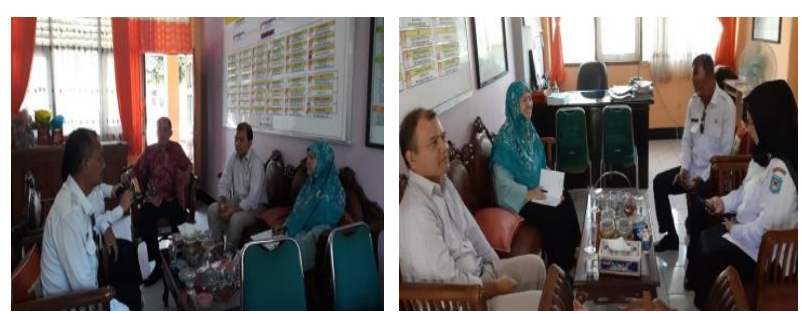

Gambar 2. Foto saat tahap persiapan, diskusi dengan kepala sekolah, wakil kepala sekolah dan guru IPA
Kegiatan sosialisasi dilaksanakan pada hari Sabtu, 23 Maret 2019. Kegiatan sosialisasi ini dihadiri oleh perwakilan Dinas Pendidikan Kota Mataram, Kepala sekolah dan Wakasek, guru guru IPA serta siswa-siswa peserta pembinaan olimpiade.

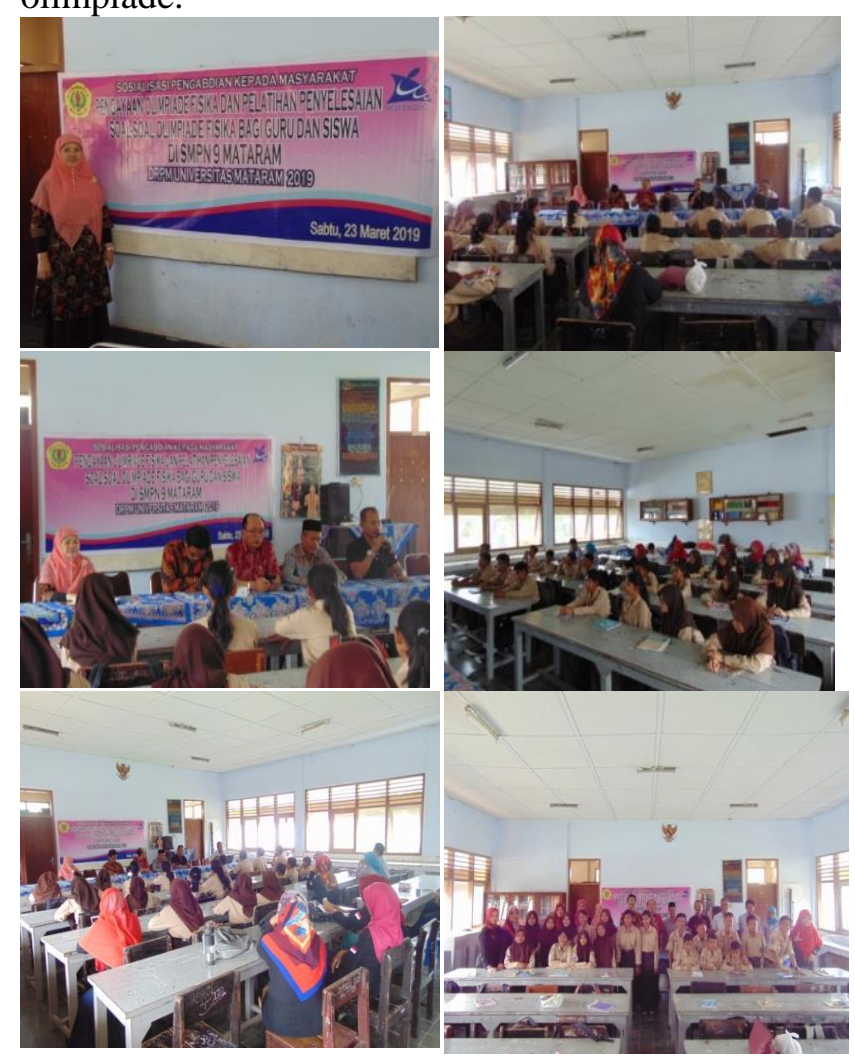

Gambar 3. Kegiatan Sosialisasi

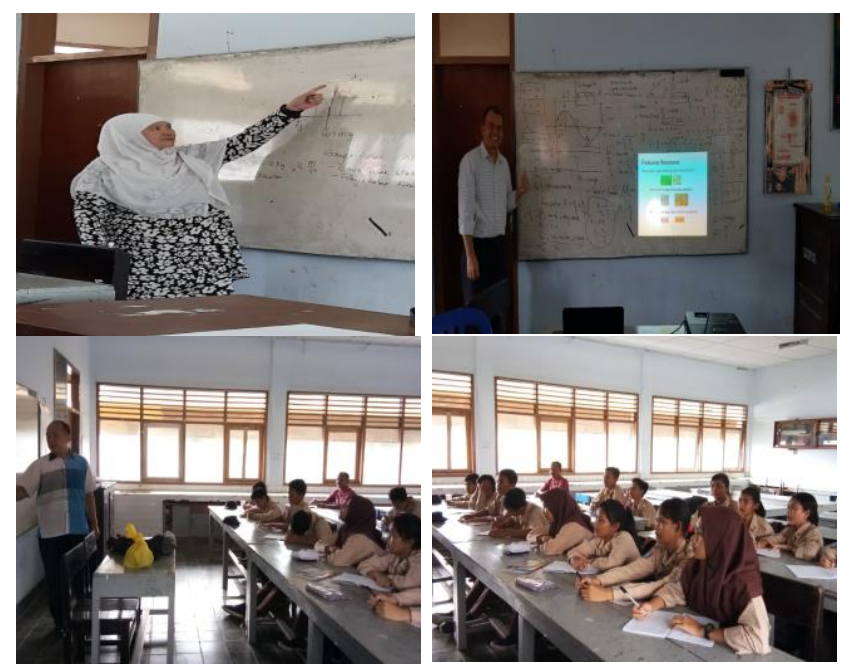

Gambar 4. Beberapa foto kegiatan pembinaan oleh dosen tim pengabdian

Melalui sosialisasi kegiatan ini, tim pengabdian mengetahui bahwa sekolah mitra khususnya SMPN 9 Mataram sangat menerima 
kegiatan pembinaan dan sangat membutuhkan pembinaan baik kepada guru agar mampu membimbing siswa dalam mengikuti olimpiade

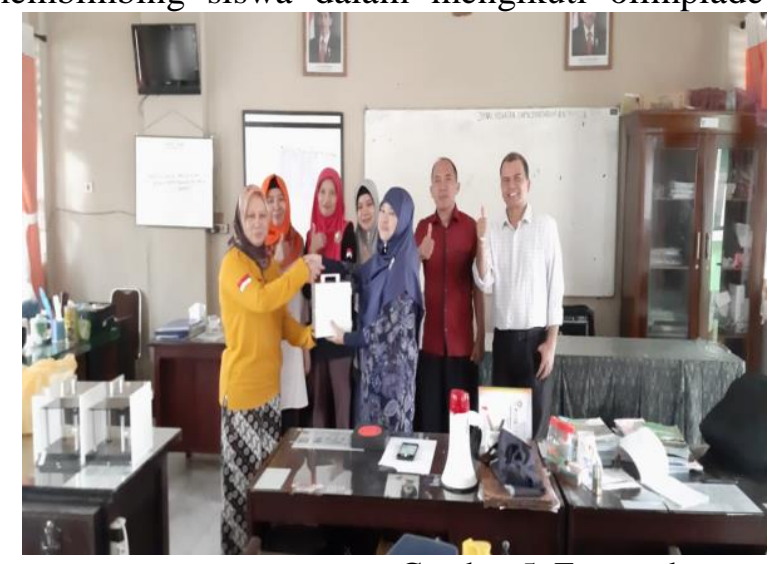

Gambar 5. Foto pada saat pembinaan pada guru-guru IPA
2019/2020. Oleh karena itu, siswa-siswa yang mengikuti pembinaan ini mestinya memiliki kemampuan akademik yang unggul (lebih baik)

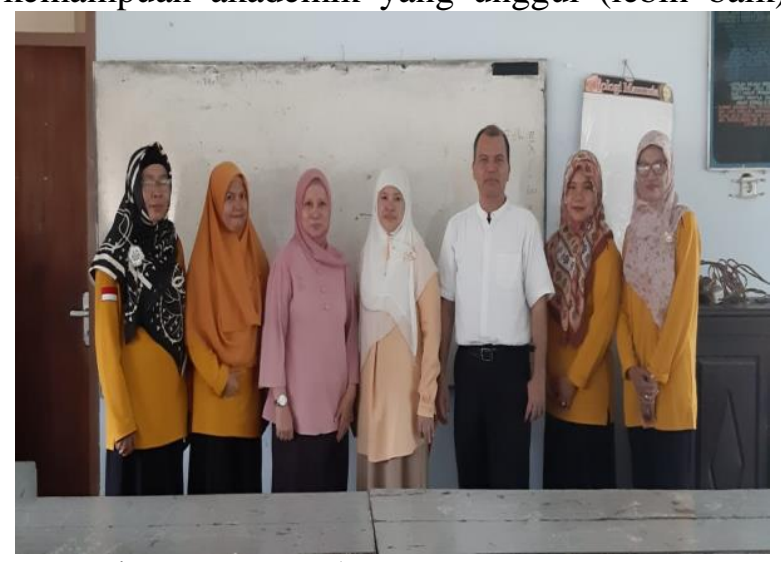

dan kepada siswa.

Kegiatan pembinaan guru dan siswa dilakukan seminggu sekali setiap hari sabtu setelah jam pelajaran sekolah usai. Sehingga dalam satu bulan ada 4 (empat) kali pembinaan baik guru maupun siswa. Setelah guru mendapat pengayaan tentang materi dan soal-soal olimpiade selanjutnya guru akan membina siswa dengan dipantau oleh dosen, untuk lebih memantapkan kemampuan guru dalam membimbing siswa-siswa dalam menyelesaikan soal-soal olimpiade.

Kegiatan pembinaan olimpiade fisika ini dilaksanakan di SMPN 9 Mataram. Dalam hal ini, pembinaan olimpiade fisika bagi siswa dilaksanakan di ruang kelas dan ruang laboratorium IPA, untuk kegiatan guru dilakukan di ruang guru dan laboratorium IPA pembinaan dilakukan setelah selesai proses pembelajaran regular yakni pukul 12.30 wita.

Pembinaan olimpiade fisika ini berlangsung selama tujuh bulan, yakni dari bulan Maret 2019 sampai September 2019. Pembinaan dilaksanakan setiap hari Sabtu setiap minggunya untuk guru dan siswa. Setiap kegiatan berlangsung dari pukul 12.30 sampai dengan 15.00 wita. Narasumber dalam kegiatan Pembinaan Olimpiade di SMPN 9 Mataram adalah: 1) Dra. Susilawati, M.Si., Ph.D., 2) Drs. Aris Doyan, M.Si., Ph.D., dan 3) Muhamad Taufik, M.Si.

Peserta kegiatan Pembinaan Olimpiade fisika di SMPN 9 Mataram adalah sejumlah lima orang guru IPA. Untuk siswa ada 20 orang yang kesemuanya berasal dari kelas VII dan VIII yang berpotensi untuk dapat lolos dalam kompetisi Olimpiade terutama mata pelajaran fisika, tahun daripada siswa-siswa yang lainnya, terutama dalam mata pelajaran IPA (fisika).

Bentuk kegiatan Pembinaan Olimpiade fisika di SMPN 9 Mataram adalah pertemuan berbentuk tambahan pelajaran. Pertemuan dilakukan sekali dalam seminggu. Pertemuan berlangsung selama dua setengah jam. Dalam tiap jam diberikan latihan-latihan soal MIPA, khususnya soal-soal yang setingkat Olimpiade Nasional. Soal-soal seperti ini bukanlah soal-soal yang biasa ditemukan untuk ujian semesteran maupun ujian akhir. Soal-soal Olimpiade tingkat SMP justru hampir menyamai soal-soal setingkat siswa di SMA.

Kegiatan inti pengabdian mulai dilaksanakan dari tanggal 30 Maret 2019. Kegiatan yang dilakukan adalah pembinaan guru pembimbing olimpiade yang dilaksanakan oleh tim pengabdian sebagai narasumber Drs. Aris Doyan, M.Si., Ph.D dan Dra. Susilawati, M.Si.Ph.D dan Muhammad Tafik, M.Si, membahas tentang metode menganalisis dalam memecahkan soal-soal olimpiade dalam materi Besaran dan Satuan, Kinematika meliputi Gerak Lurus Beraturan (GLB) dan Gerak Lurus Berubah Beraturan (GLBB). Kegiatan pembinaan siswa dilaksanakan oleh Muhammad Taufik, S.Pd., M.Si. membahas tentang materi dan soal-soal olimpiade Gerak Lurus.

Pelaksanaan yang berikutnya dengan materi perpaduan GLB dan GLBB dan Dinamika yang meliputi Gaya, Momentum, Impuls dan Energi. GLBB dengan arah horizontal dan arah vertikal yakni gerak vertikal ke atas, gerak vertikal ke bawah, dan gerak jatuh bebas, serta perpaduan 
GLB dan GLBB (gerak parabola) baik bagi guru dan siswa yang disampaikan oleh semua Tim pengabdian. Penyampaian materi fisika juga disertai latihan dalam menyelesaikan soal-soal olimpiade bagi guru dan siswa.

Tahap Evaluasi, secara umum pelaksanaan kegiatan Pembinaan Olimpiade berjalan dengan baik. Sebagaimana disebutkan di atas, pelaksanaan pembinaan ini dilaksanakan dalam bentuk tambahan pelajaranyang berlangsung selama dua setengah jam, dimulai jam $12.30 \mathrm{~s} / \mathrm{d}$ 15.00. Jadwal ini setelah jadwal mata pelajaran reguler. Tiap pertemuan diisi dengan berbagai latihan soal terutama soal-soal ditingkat Olimpiade. Pertama, setiap siswa diminta untuk mengerjakan berbagai soal-soal Olimpiade secara mandiri maupun bekerjasama dengan teman sebangku. Hal ini dilakukan selama kurang lebih enam puluh menit. Dalam setiap pertemuan diusahakan agar siswa-siswa tersebut dapat mengerjakan tiga sampai lima soal-soal olimpiade Sains. Kedua, narasumber (pembina) membahas satu sampai dua soal. Untuk membahas satu buah soal olimpiade tidaklah sederhana karena memang tingkatannya tinggi. Satu soal membutuhkan sekitar tiga puluh menit untuk dibahas dengan baik. Pembahasan soal menjadi penting sekali agar siswa-siswa menjadi paham untuk mengerjakan soal-soal lain yang sejenis. Salah satu indikator yang penting dalam kompetisi olimpiade adalah terbiasa mengerjakan soal-soal setingkat SMA.

Pembinaan ini bertujuan untuk membiasakan siswa-siswa dengan soal olimpiade. Selain itu, tujuan lain dari pembinaan ini adalah menumbuhkan intuisi agar siswa dapat beradaptasi dengan cepat dengan berbagai soal yang berbeda. Selama pembinaan berlangsung, respon dari siswa cukup baik. Siswa bersemangat dalam mengikuti setiap pembinaan. Siswa sangat aktif mengerjakan soal-soal olimpiade yang diberikan oleh pembina. Banyak pula pertanyaanpertanyaan yang diajukan oleh siswa baik ketika mengerjakan soal-soal maupun ketika pembina memberi penjelasan tentang soal tertentu. Respon dari guru-guru juga cukup baik. Guru-guru sangat mendukung adanya pembinaan ini, terutama dalam hal mensukseskan tiap-tiap pertemuan. Guru juga menentukan ruang mana yang dapat digunakan untuk pembinaan. Pada akhirnya, tidak semua siswa yang mengikuti pembinaan ini akan diajukan untuk mengikuti kompetisi olimpiade. Selama pembinaan ini terjadi pula proses seleksi.

\section{Kesimpulan}

Secara umum, pembinaan olimpiade Sains ini telah berjalan dengan baik dan mencapai tujuannya, para peserta baik guru maupun siswa mendapat pengalaman dan mendapatkan wawasan, serta seluk beluk olimpiade fisika di tingkat SMP. Dengan hasil kegiatan pembinaan olimpiade yang baik ini, maka perlu dilanjutkan di masa yang akan datang. Hal ini perlu dilakukan agar tetap terjadi kesinambungan prestasi akademik khususnya untuk olimpiade fisika di SMPN 9 Mataram.

\section{Saran}

Pengayaan dan pelatihan materi olimpiade ini sudah berjalan dengan lancar, namun dalam kegiatan hendaknya disajikan media pembelajaran untuk membantu siswa agar materi menjadi konkret.

\section{Ucapan Terima Kasih}

Tim pengabdian mengucapkan terima kasih kepada kementerian riset, teknologi, dan pendidikan tinggi yang telah membiayai kegiatan pengabdian ini dengan nomor kontrak 065/SP2H/PPM/DRPM/2019.

\section{Daftar Pustaka}

Anonim. 1991. Kamus Besar Bahasa Indonesia Edisi II. Jakarta: Balai Pustaka.

Depdiknas. 2018. Kisi-kisi Olimpiade Sains Tingkat SMP. Jakarta: Depdiknas

Hidayat, T,. 2018. OSN Fisika SMP. Yogyakarta: Penerbit Andi.

Supriyadi. 2007. Kurikulum Sains dalam Proses Pembelajaran Sains. Yogyakarta: PustakaTempel Sari

Wikipedia. 2018. Olimpiade Sains Nasional. Tersedia Online. https://id.wikipedia.org/wiki/Olimpiade_Sa ins_Nasional. Diakses. 25 februari 2019. 